Review article

\title{
DNA vaccination against Chlamydiaceae: current status and perspectives
}

\author{
Céline HÉCHARD, Olivier GRÉPINET* \\ Unité de Pathologie Infectieuse et Immunologie, INRA-Centre de Tours, 37380 Nouzilly, France
}

(Received 27 August 2003; accepted 7 October 2003)

\begin{abstract}
DNA vaccination (also called genetic vaccination) recently celebrated its ten years of existence. This new method of immunization presents several advantages, including the induction of both humoral and cellular immune responses. This vaccination strategy has been very successful and has served as a basis for numerous experiments that had the aim of resolving parasitic, viral, and bacterial infections. In particular, DNA vaccination has been evaluated against Chlamydiaceae, small obligate intracellular bacteria, that induce many pathologies in humans and animals. Despite promising protective effects obtained in murine and turkey models with genes encoding outer membrane proteins and heat shock proteins, DNA vaccination against Chlamydiaceae must be optimized by further investigations and could benefit from the genomic sequencing in terms of the identification of new antigens.
\end{abstract}

DNA vaccination / Chlamydia / Chlamydophila

Table of contents

1. Introduction.

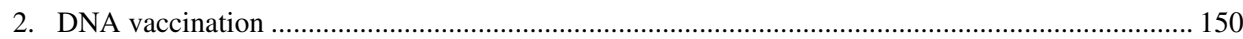

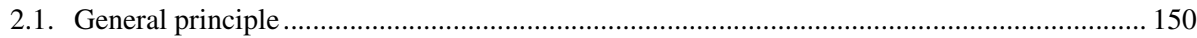

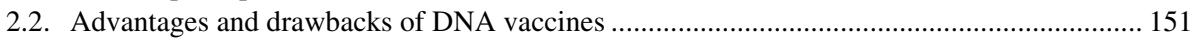

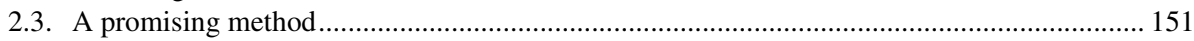

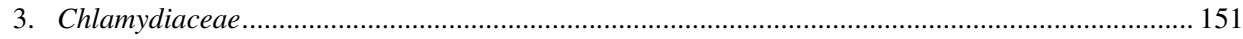

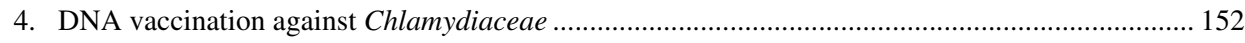

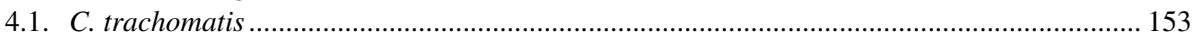

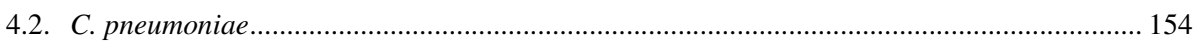

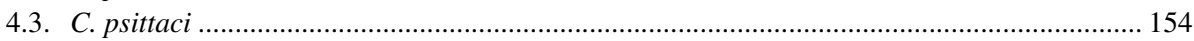

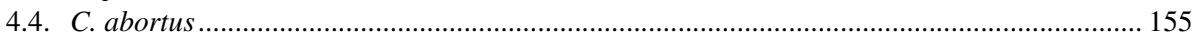

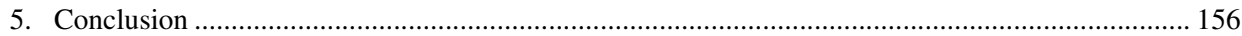

\footnotetext{
* Corresponding author: grepinet@tours.inra.fr
} 


\section{INTRODUCTION}

The concept of DNA vaccines was born in 1989 from the collaboration of a team from the University of Wisconsin and scientists at Vical Inc. (San Diego, CA, USA) who were involved in gene therapy. A bacterial plasmid DNA was injected into mouse skeletal muscle in vivo without any special delivery system. This plasmid contained a reporter gene and the authors showed that the corresponding protein was expressed in the skeletal muscle for at least two months [94]. A few years later, it was demonstrated that the intramuscular injection of a plasmid encoding an antigenic foreign gene could elicit the production of antibodies [82] and led to the protection of mice against influenza infection [86]. DNA immunization was then tested against a large number of viral, parasitic, and bacterial pathogens. Partial and even complete protection has been conferred in several murine models, but the results in target animals have been often disappointing. Despite these difficulties, DNA vaccines represent an alternative approach to conventional vaccines and numerous trials of DNA vaccination in veterinary species are reported in the literature [20].

Chlamydiaceae are pathogenic bacteria which induce various and major diseases in humans and animals [44]. Thus, the development of efficient vaccines against the different species of Chlamydiaceae has become a priority over the last twenty years. Besides the conventional vaccines such as inactivated or attenuated organisms and acellular outer membrane complex preparations, many subunits and DNA vaccines have been designed and tested in animal models [34, 43].

\section{DNA VACCINATION}

\subsection{General principle}

The DNA immunization consists in the direct transfer of a naked bacterial plasmid
DNA into the animal cells $[14,15]$. The gene encoding an immunogenic protein is first inserted in a eukaryotic expression plasmid. In essence, the vector contains a prokaryotic replication origin that allows production of the plasmid in bacteria, an antibiotic resistance gene for selective growing, a strong viral promoter and a polyadenylation/transcriptional termination sequence for the expression of the cloned gene in mammalian cells [37]. The vaccinal plasmid is then delivered into the host and is taken up by host cells where the encoded protein is synthesized. This protein recognized as a foreign antigen becomes the target of the host immune system; the antigenic protein is processed and presented to the immune system where it induces a broad range of immune responses [19, 27, 42, 73]. The DNA vaccination can generate a specific humoral immunity, mediated by $\mathrm{CD} 4^{+}$ $\mathrm{T}$ lymphocytes and characterized by the production of antigen-specific antibodies, and a cellular response, including the activation of $\mathrm{CD} 8^{+} \mathrm{T}$ lymphocytes, essential for the protection against intracellular pathogens. The induction of a cytotoxic T lymphocyte response involves both direct transfection of antigen-presenting cells (APC) and cross-priming of APC by the antigen synthetised in muscle cells [85].

Different methods of delivery are used to introduce nucleic acid vaccines into animal cells and tissues [1]. Naked DNA vaccines are usually administered either by intramuscular and intradermal injections, but can also be delivered through intranasal, intravaginal and oral injections. More recently, promising new methods of administration have been tested, including in vivo electroporation [92] and direct injection into a peripheral lymph node [47]. Intramuscular immunization can only be performed with a simple needle, while intradermal immunization can be done with a needle or a gene gun. The gene gun allows particle-mediated delivery which favorably reduces the necessary amount of DNA compared to a needle injection, however this method is less easy to perform. DNA 
immunization elicits both humoral and cellular immune responses. The type of immune response depends on the DNA delivery method. Indeed, intramuscular immunization induces a Th1-biased immune response, which rather involves a cellular response, while a gene gun immunization induces a more balanced Th1/Th2 immune response, depending on the amount of plasmid DNA administered [6].

\subsection{Advantages and drawbacks of DNA vaccines}

DNA vaccines have various advantages. They are easy and cheap to produce, store, and use [24]. They are also devoid of any risk of reversion and adverse side-effects encountered with conventional attenuated vaccines. Furthermore, DNA vaccines induce humoral and cellular responses specific to a unique protein [19] and can therefore be considered as marker vaccines. Consequently, they allow us to distinguish the infected subjects from the vaccinated ones in a population. However, despite these numerous advantages, some risks remain [51]. First, the integration of the injected vaccinal DNA could occur in the genome of the host cell $[48,57]$. Then, repeated injections could lead to an immunological tolerance [53] or induce autoimmunity [52]. Finally, injected DNA could induce an immune response against the plasmid DNA itself [64]. Even if these dangers have been underlined, no study has been able to confirm these hypotheses, yet.

\subsection{A promising method}

DNA vaccination has already been successfully used against human and animal pathogens $[1,3,19,58]$. It seems to be particularly adapted to the fight against intracellular bacteria [21, 27, 79] because it induces the same mechanisms as the ones necessary for eradication of the infection by these pathogens [32]. One of the best results has been achieved in a tuberculosis model. Indeed, a significant protection against an infectious challenge with Mycobacterium tuberculosis was notably obtained after mice immunization with DNA encoding the heat shock proteins (Hsps) Hsp65 and Hsp70 [45, 83]. In this case, DNA vaccination also had a therapeutic action on the established infection [46].

DNA vaccines represent a powerful and novel entry into the field of immunological control of diseases. Nevertheless, further investigations are necessary in order to utilize the full potential of this technology [41].

\section{CHLAMYDIACEAE}

Chlamydiaceae are obligate, intracellular, Gram-negative bacteria that are pathogenic for humans and animals. Their unique and complex developmental cycle is characterized by an infectious extracellular form, the elementary body, and a metabolically active intracellular form, the reticulate body. A recent classification [23] distinguishes Chlamydia and Chlamydophila genera in the Chlamydiaceae family. The Chlamydia genus contains three species: Chlamydia trachomatis, Chlamydia suis and Chlamydia muridarum while the Chlamydophila genus contains six species: Chlamydophila caviae, Chlamydophila felis, Chlamydophila pecorum, Chlamydophila pneumoniae, Chlamydophila psittaci, and Chlamydophila abortus.

Chlamydiaceae infections result in various diseases (Tab. I), including trachoma, pneumonia, rhinitis, conjunctivitis, arthritis, abortion or enteritis, as well as asymptomatic infections [22]. Since the end of the 19th century, there have been significant efforts to develop vaccines against these bacteria. Except for the attenuated living vaccines $[56,68]$, the classical immunizing strategies with whole-organism, attenuated vectors, or even subunit vaccines from Chlamydiacae have given only moderate results [74]. Consequently, DNA vaccines represent an opportunity for researchers to 
Table I. Pathogenesis of Chlamydiaceae (according to Everett [22]).

\begin{tabular}{|c|c|c|}
\hline Species & Host(s) & Main clinical manifestations \\
\hline \multicolumn{3}{|l|}{ Chlamydia } \\
\hline trachomatis & Humans & Trachoma, urogenital infections \\
\hline suis & Swine & Conjunctivitis, enteritis, pneumonia, asymptomatic infections \\
\hline muridarum & Mice, hamsters & Pneumonia, asymptomatic infections \\
\hline \multicolumn{3}{|l|}{ Chlamydophila } \\
\hline caviae & Guinea pig & Conjunctivitis, genital infections \\
\hline felis & Cats & Conjunctivitis, rhinitis \\
\hline pecorum & $\begin{array}{l}\text { Koala, cattle, sheep, } \\
\text { goats, swine }\end{array}$ & Abortion, conjunctivitis, enteritis, pneumonia \\
\hline pneumoniae & Humans, koala, horses & Respiratory infections (bronchitis, pneumonia) \\
\hline psittaci & Birds & Respiratory and gastrointestinal infections, conjunctivitis \\
\hline abortus & Small ruminants & Abortion \\
\hline
\end{tabular}

Table II. Chlamydiaceae genes tested in DNA vaccination.

\begin{tabular}{|c|c|c|c|}
\hline Species & Antigens & Animal model & References \\
\hline C. trachomatis $\mathrm{L} 2$ & MOMP & Mouse & [79] \\
\hline C. muridarum (strain $\mathrm{MoPn})^{\mathrm{a}}$ & MOMP, CTP synthetase & Mouse & {$[95,96]$} \\
\hline C. muridarum (strain MoPn) & MOMP, variable domains of the MOMP & Mouse & [60] \\
\hline C. muridarum (strain MoPn) & MOMP & Mouse & [18] \\
\hline C. trachomatis $\mathrm{GO} / 86$ & pgp3 & Mouse & [17] \\
\hline C. pneumoniae & Omp2 & Mouse & [80] \\
\hline C. pneumoniae AR-39 & Panel of ORF & Mouse & [54] \\
\hline C. pneumoniae $\mathrm{K} 6$ & Hsp60 (GroEL) & Mouse & [81] \\
\hline C. pneumoniae $\mathrm{K} 6$ & MOMP, Hsp60, Omp2 & Mouse & [62] \\
\hline C. psittaci $84 / 55$ & MOMP & Turkey & [89-91] \\
\hline C. abortus $\mathrm{AB} 7$ & DnaK (Hsp70) & Mouse & {$[29,31]$} \\
\hline C. abortus $\mathrm{AB} 7$ & MOMP & Mouse & [30] \\
\hline
\end{tabular}

a Previously named $C$. trachomatis MoPn.

explore a novel method of vaccination against these bacterial pathogens. DNA immunization is now known to induce both humoral and cellular immune responses [19] which are especially suited to fight against intracellular bacteria [79]. In this review, we will refer to the different DNA vaccination tests elaborated to resolve some of the Chlamydiaceae infections.

\section{DNA VACCINATION AGAINST CHLAMYDIACEAE}

The majority of DNA immunization trials against Chlamydiaceae deals with the species that are directly pathogenic for humans, C. trachomatis and C. pneumoniae, or the ones that also cause zoonotic diseases, C. psittaci and C. abortus (Tab. II). 
DNA immunization experiments are usually performed on mice models. However, in the case of $C$. psittaci, the experiments were conducted in the target animal, the turkey. The protective effect of DNA immunization is generally evaluated by the comparison between the effects observed in animal groups immunized with the empty plasmid (negative control), with the vaccinal plasmid and with a conventional vaccine (positive control).

\subsection{C. trachomatis}

C. trachomatis causes human trachoma and sexually transmitted diseases, as well as some forms of arthritis, neonatal conjunctivitis and pneumonia. At present, the predominant antigen used in DNA vaccination trials against $C$. trachomatis has been the major outer membrane protein (MOMP) encoded by the ompA gene (Tab. II). Indeed, the MOMP appears to be the principal candidate for protective immune response. It generates both strong humoral and cellular immune responses in mice models. Moreover, anti-MOMP monoclonal antibodies offer the capacity to neutralize the infectivity of the bacteria in vitro as well as in vivo [5, 59, 61, 63, 75]. Immunization of BALB/c mice with three intramuscular injections of a MOMP encoding plasmid induces a MOMP-specific delayed-type hypersensitivity reaction (DTH), a lymphocyte proliferation, an interferon- $\gamma($ IFN- $\gamma)$ production and a weak humoral response suggesting a Th1 immune response [95, 96]. These humoral and cellular responses reduce the number of chlamydial inclusions in the lungs after an intranasal challenge with $10^{4}$ inclusion forming units (ifu) of C. trachomatis [96]. Nevertheless, the same vaccinal protocol failed to protect mice against an intravaginal challenge with $10^{6}$ ifu, while no reduction of the chlamydial number was observed in vaginal cultures [60]. Thus, it appears that the type of challenge plays a major role in the success of DNA vaccination.
In order to stimulate immune responses, mice were primed with DNA and boosted with the corresponding proteins. The mice were intramuscularly primed with MOMP plasmid DNA on three occasions and were boosted with an MOMP immune-stimulating complex (ISCOM) [18]. Stronger immune responses were obtained in mice given combinational immunization than in mice given MOMP-ISCOM vaccination alone. This was correlated with a significant reduction of the number of bacterial inclusions in the lungs of mice vaccinated with MOMP DNA and boosted with MOMP-ISCOM after an intranasal challenge [18]. Unfortunately, the protective effect of this kind of vaccination was not evaluated after a genital challenge; nevertheless, it is believed that it will likely protect from a genital challenge as well. Indeed, it has already been shown that a transfer of $\mathrm{T}$ cells taken from mice vaccinated with ISCOM-MOMP alone protect naive recipient mice from a genital challenge [33]. Moreover, the protective effect of DNA/MOMP-ISCOM vaccination against an intranasal challenge was enhanced when compared to the one resulting from vaccination with MOMP-ISCOM alone. However, to confirm this hypothesis, it would be of significant interest to evaluate the protection induced by the protocol used by Dong-Ji et al. [18] (i.e. DNA/ MOMP-ISCOM) against a genital challenge. It is also important to emphasize that the quantity of Chlamydia used for bacterial challenge varies considerably in these studies. It would be of interest to carry out challenges with the same dose of bacteria, in order to accurately compare the protective effect in different DNA vaccination trials.

The other antigens tested in DNA vaccination trials against $C$. trachomatis include the cytosine triphosphate (CTP) synthetase [96] and the plasmid antigen pgp3 [17]. Although DNA immunization with the CTP synthetase gene elicited a significant humoral response, it did not induce any protection. DNA vaccination with the pgp3 gene elicited both humoral and mucosal 
antibodies and was partially protective against a genital challenge.

DNA vaccination efficiency depends on the delivery method, the route and the dose of the challenge, as well as the mice strain. Nevertheless, DNA vaccines are emerging as a promising new approach to protect humans from chlamydial infections. Further investigations are required for DNA vaccination optimization, as well as for testing its protective effect in the target species of $C$. trachomatis, i.e. humans.

\subsection{C. pneumoniae}

C. pneumoniae induces a large range of human respiratory diseases including pharyngitis, bronchitis, and pneumonia [25]. It has also recently been associated with cardiovascular diseases [70].

As in cases of $C$. trachomatis, DNA vaccination trials against $C$. pneumoniae used the ompA gene. One study showed that three MOMP DNA injections every three weeks with combined intranasal and intramuscular delivery enhance the bacterial clearance in the lung and induce a 12-fold reduction of ifu after an intranasal challenge and a moderate protection of $\mathrm{BALB} / \mathrm{c}$ mice [54]. Moreover, a recent report of DNA vaccination (three intramuscular DNA injections in each quadriceps every three weeks) failed to induce specific antibodies against recombinant MOMP, but stimulated a cellular response that protected mice against an intranasal challenge. The mice immunized with the ompA gene showed $1.2 \mathrm{log}$ lower mean ifu counts in the lungs compared to the mice that received the control vector [62]. These promising results confirmed that the MOMP of C. pneumoniae was immunogenic [93], although it was commonly admitted that the $C$. pneumoniae MOMP was immunorecessive and not surface exposed, and that it was not the predominant serotype antigen of $C$. pneumoniae [10-12].

Other C. pneumoniae antigens were tested in DNA immunization experiments, including the protein of the outer mem- brane, Omp2, and the Hsp GroEL (Hsp60) $[62,80,81]$. These two proteins are actually considered as potent immunogens $[38,55]$. Three intramuscular injections (every three weeks) of the Omp2-encoding gene induced a humoral response, although they failed to reduce the bacterial ifu in the lung after the intranasal challenge. However, the same protocol realized with the GroEL-encoding gene induced a cellular immune response and partially lowered the bacterial load in the lungs [62]. Another study also established that three intranasal injections (every two weeks) of GroEL-encoding DNA generated a protective immune response since it reduced the bacterial ifu in mice lungs after an intranasal challenge. On the contrary, intradermic immunization with the groEL gene (three injections of DNA every two weeks) induced a humoral response but failed to protect the mice [81]. It can then be concluded that the protective effect of a given antigen differs depending on the immunization protocol. Therefore, it seems important to first test the same antigen with different immunization protocols before reaching a definitive conclusion about its putative protective effect.

Murdin et al. [54] screened a panel of open-reading frames for their ability to elicit protective responses in a mouse lung challenge model. Two out of eight tested DNA immunization constructs, encoding the MOMP and an ADP/ATP translocase, could reduce the lung burden of $C$. pneumoniae after a challenge. This study demonstrates the feasibility of using a DNA immunization strategy to screen numerous antigens of a microorganism for protective efficacy.

DNA vaccination against $C$. pneumoniae is giving promising results which differ according to immunization protocols and the antigens in use. It must then be optimized in order to obtain the best protection.

\subsection{C. psittaci}

C. psittaci infects wild or captive birds and is responsible for nervous, respiratory, 
gastrointestinal, and ocular problems. The birds represent a source of contamination for humans who develop psittacosis after infection. The clinical signs of psittacosis are more or less severe [88].

Again, the effect of the MOMP-based DNA immunization was evaluated but this time, on the target animal. It prevented severe clinical manifestations and lesions in a turkey model of $C$. psittaci infection. The turkeys were immunized with simultaneous intramuscular and intranasal inoculations of MOMP DNA or with a gene gun (MOMP DNA coated on gold particles). The turkeys developed both humoral and cellular immune responses and exhibited reduced symptoms, lesions, and excretion of bacteria after an aerosol challenge [89]. Furthermore, in this model, the intramuscular inoculation, as well as the combined intranasal and intramuscular injections or aerosol delivery of MOMP DNA protected turkeys from an aerosol challenge [91].

The studies of Vanrompay et al. [89-91] had the advantage of being directly done on the target animal of the $C$. psittaci infection. Even if the target animal provides the best model, it would be of interest to test the turkey-protecting DNA vaccine on mice in order to establish if mice experiments can be extrapolated to the target animal. This murine model would also make the screening of other potential protective antigens easier. Nevertheless, DNA immunization does appear to be a promising method for bird vaccination against $C$. psittaci and needs further investigations in order to devise the best protocol for a generic use.

\subsection{C. abortus}

C. abortus infects small ruminants and colonizes the placenta [78]. Infection is primarily associated with cases of abortion and weak neonates and induces significant economic losses in breeding units. Public health should also be considered, since cases of zoonotic abortion due to C. abortus have been documented on women who have worked with sheep [8]. DNA vaccination could open important perspectives for the development of an acellular vaccine against ovine chlamydiosis which would allow the detection of infected animals in vaccinated flocks.

The DNA vaccinal strategy was tested in a pregnant and non-pregnant murine model using genes encoding MOMP [30], Hsps DnaK (Hsp70) [29, 31] and GroEL (unpublished results). The experimental protocol was identical for the three genes: outbred OF1 mice were intramuscularly immunized in each tibialis anterior three times at three week intervals and the mice were intraperitoneally challenged with the virulent strain, C. abortus AB7. In the case of the DnaK vaccination, a prime-boost strategy was also tested with a third injection consisting of recombinant DnaK protein [31]. Despite a specific humoral response directed against the proteins encoded by the injected vaccinal genes, no significant protection was found. Indeed, the DNA vaccination with these genes failed to significantly reduce the abortion cases, as well as the $C$. abortus quantities in the spleens, placentas, and fetuses of mice after the challenge, especially in comparison with the effect of the temperature-sensitive mutant 1B [68], which protects mice very efficiently against C. abortus and is currently being used as a positive control of immunization. The protein boost with the recombinant DnaK protein substantially increased the antibody level, but as for the two other antigens tested, the induced antibodies had no in vitro neutralizing properties on $C$. abortus infectivity [31].

Despite the antigenic properties of MOMP, DNA vaccination with this antigen elicited a weak humoral response and failed to protect pregnant mice from abortion against $C$. abortus challenge [30]. Since protective anti-MOMP antibodies are known to be directed against conformational epitopes [16, 49], we could speculate that the MOMP DNA vaccine induced linear epitope-specific antibodies. DNA 
immunization with these three antigens induced predominantly IgG2a antibodies, suggesting a Th1-type immune response. This Th1-biased immune response is caused by the immunostimulating properties of the unmethylated $\mathrm{CpG}$ motifs present in the vaccinal plasmid backbone [39]. Buendía et al. [7] reported high levels of IFN- $\gamma$ and interleukin-12 in the serum of mice infected with the C. abortus strains $\mathrm{AB} 7$ and 1B, suggesting strongly that effective resolution of the infection involves a Th1-like immune response.

Preliminary results on the validation of DNA vaccine constructs encoding the MOMP of C. abortus have been reported by Coulter et al. [13]. The different constructs bearing the ompA gene, with or without the leader sequence and with or without a Kozak modification, were tested in vitro and in vivo for MOMP expression before performing DNA vaccination experiments in mice and sheep.

Since the humoral immune response is known to play a less important role in the resolution of $C$. abortus infection than the cellular immune response [9], further investigations must be done to identify the antigens that are able to induce an efficient cellular immune response. The model usually employed for the evaluation of C. abortus virulence [69] and vaccine efficiency [68] is the OF1 outbred murine model of abortion which does not allow an extensive analysis of the cellular immune response. Therefore, it would be of interest to screen the selected antigens in an inbred murine model in order to study the induced cellular immune response in detail. A DNA vaccination trial could also be performed on small ruminants (sheep or goat), in order to evaluate the protective effect of these antigens in the target animals.

\section{CONCLUSION}

DNA vaccination is a promising method to fight against intracellular bacteria since it can efficiently induce a cellular immune response. Indeed, it provided undeniably satisfactory results in the case of tuberculosis [84]. Nevertheless, the results obtained using Chlamydiaceae models remain modest and further investigations are necessary in order to improve them. The immunization protocol should be optimized appropriately, since it is now established that a broad range of factors, including the route of immunization, the mice species, and the age of the mice can influence the outcome of such a vaccination [6]. Finally, prime-boost immunization strategies could be tested, since they have been shown to enhance the levels of induced cellular immunity [50]. The use of such a strategy has effectively improved the protection, as well as the cellular immune response in a $C$. trachomatis murine model of infection [18].

DNA vaccination is often more efficient in mice than in large animals which are the target species. The immune response induction and the protective effect of DNA vaccines have been evaluated on different animal species [2], but the high animal cost and the limited number of immunological reagents makes trials on target species more difficult [87]. The aim of numerous experiments was to improve the immunogenicity of DNA vaccines in large animals by increasing the level of expression of the antigen and the transfection efficiency [4]. Nevertheless, the challenge is now to demonstrate that there is an economical way to induce protective immune responses in livestock under various management systems [3].

Moreover, it would be of particular interest to identify new potential vaccine candidates for DNA vaccination against Chlamydiaceae. In this respect, the recent sequencing of $C$. trachomatis (serovars D and L2) [77], C. muridarum (strain MoPn) [66], C. pneumoniae (strains AR39, CWL029 and $\mathrm{J} 138)[36,66,72]$ and $C$. caviae (strain GPIC) [65] genomes will permit, on the one hand, an increase in knowledge of Chlamydiaceae [67], and, on the other hand, the 
identification of novel antigen candidates for DNA vaccination [76]. Another potentially interesting study would be to implement an expression library immunization and to screen it in vitro, as well as in vivo, for its protective effect. Such a novel approach could result in a rapid method for isolating protective genes from a pathogen and could become very useful, especially for microorganisms that are difficult to grow or attenuate, such as Chlamydiaceae $[35,40]$.

In conclusion, DNA immunization can represent an efficient method to fight against Chlamydiaceae infections in the future, but must still be the subject of further experiments, including the use of a genetic adjuvant such as cytokines and costimulatory cell surface molecules [26, 40,71], the optimization of the plasmid design, the gene selection, the route and the dosage of DNA vaccines [28].

\section{ACKNOWLEDGEMENTS}

We are grateful to Dr. Annie Rodolakis for critically reviewing the manuscript and to Edward Balaban for the assistance with our English. This work was supported by a doctoral grant from INRA-Région Centre.

\section{REFERENCES}

[1] Alarcon J.B., Waine G.W., McManus D.P., DNA vaccines: technology and application as anti-parasite and anti-microbial agents, Adv. Parasitol. 42 (1999) 343-410.

[2] Babiuk L., van Drunen Littel-van den Hurk S., Babiuk S., Immunization of animals: from DNA to the dinner plate, Vet. Immunol. Immunopathol. 72 (1999) 189-202.

[3] Babiuk L., Babiuk S., Loehr B., van Drunnen Littel-van den Hurk S., Nucleic acid vaccines: research tool or commercial reality, Vet. Immunol. Immunopathol. 76 (2000) 1-23.

[4] Babiuk L.A., Pontarollo R., Babiuk S., Loehr B., van Drunen Littel-van den Hurk S., Induction of immune responses by DNA vaccines in large animals, Vaccine 21 (2003) 649-658.
[5] Baehr W., Zhang Y.X., Joseph T., Su H., Nano F.E., Everett K.D., Caldwell H.D., Mapping antigenic domains expressed by Chlamydia trachomatis major outer membrane protein genes, Proc. Natl. Acad. Sci. USA 85 (1988) 4000-4004.

[6] Barry M.A., Johnston S.A., Biological features of genetic immunization, Vaccine 15 (1997) 788-791.

[7] Buendía A.J., Sánchez J., Del Rio L., Garcés B., Gallego M.C., Caro M.R., Bernabé A., Salinas J., Differences in the immune response against ruminant chlamydial strains in a murine model, Vet. Res. 30 (1999) 495507.

[8] Buxton D., Potential danger to pregnant women of Chlamydia psittaci from sheep, Vet. Rec. 118 (1986) 510-511.

[9] Buzoni-Gatel D., Rodolakis A., Plommet M., $\mathrm{T}$ cell mediated and humoral immunity in a mouse Chlamydia psittaci systemic infection, Res. Vet. Sci. 43 (1987) 59-63.

[10] Campbell L.A., Kuo C.C., Grayston J.T., Structural and antigenic analysis of Chlamydia pneumoniae, Infect. Immun. 58 (1990) 93-97.

[11] Campbell L.A., Kuo C.C., Wang S.P., Grayston J.T., Serological response to Chlamydia pneumoniae infection, J. Clin. Microbiol. 28 (1990) 1261-1264.

[12] Christiansen G., Boesen T., Hjernø K., Daugaard L., Mygind P., Madsen A.S., Knudsen K., Falk E., Birkelund S., Molecular biology of Chlamydia pneumoniae surface proteins and their role in immunopathogenicity, Am. Heart J. 138 (1999) S491-S495.

[13] Coulter L.J., Sinclair M.C., Livingstone M., Maley S.W., Buxton D., Longbottom D., Validation of DNA vaccine constructs for Chlamydophila abortus protection studies, Res. Vet. Sci. 72 Suppl. A (2002) 24.

[14] Danko I., Wolff J.A., Direct gene transfer into muscle, Vaccine 12 (1994) 1499-1502.

[15] Davis H.L., Michel M.L., Mancini M., Schleef M., Whalen R.G., Direct gene transfer in skeletal muscle: plasmid DNA-based immunization against the hepatitis $B$ virus surface antigen, Vaccine 12 (1994) 1503-1509.

[16] De Sa C., Souriau A., Bernard F., Salinas J., Rodolakis A., An oligomer of the major outer membrane protein of Chlamydia psittaci is recognized by monoclonal antibodies which protect mice from abortion, Infect. Immun. 63 (1995) 4912-4916.

[17] Donati M., Sambri V., Comanducci M., D Leo K., Storni E., Giacani L., Ratti G. Cevenini R., DNA immunization with pgp3 
gene of Chlamydia trachomatis inhibits the spread of chlamydial infection from the lower to the upper genital tract in $\mathrm{C} 3 \mathrm{H} / \mathrm{HeN}$ mice, Vaccine 21 (2003) 1089-1093.

[18] Dong-Ji Z., Yang X., Shen C., Lu H., Murdin A., Brunham R.C., Priming with Chlamydia trachomatis major outer membrane protein (MOMP) DNA followed by MOMP ISCOM boosting enhances protection and is associated with increased immunoglobulin $\mathrm{A}$ and Th1 cellular immune responses, Infect. Immun. 68 (2000) 3074-3078.

[19] Donnelly J.J., Ulmer J.B., Shiver J.W., Liu M.A., DNA vaccines, Annu. Rev. Immunol. 15 (1997) 617-648.

[20] Dufour V., DNA vaccines: new applications for veterinary medicine, Vet. Sci. Tomorrow, Issue 2 [on line] (2001) http://www.vetscite.org/cgi-bin/pw.exe/issue2/000022/ 000022.htm [consulted 24 January 2003].

[21] Eissenberg L.G., Wyrick P.B., Davis C.H., Rumpp J.W., Chlamydia psittaci elementary body envelopes: ingestion and inhibition of phagolysosome fusion, Infect. Immun. 40 (1983) 741-751.

[22] Everett K.D.E., Chlamydia and Chlamydiales: more than meets the eye, Vet. Microbiol. 75 (2000) 109-126.

[23] Everett K.D.E., Bush R.M., Andersen A.A., Emended description of the order Chlamydiales, proposal of Parachlamydiaceae fam. nov. and Simkaniaceae fam. nov., each containing one monotypic genus, revised taxonomy of the family Chlamydiaceae, including a new genus and five new species, and standards for the identification of organisms, Int. J. Syst. Bacteriol. 49 (1999) 415-440.

[24] Ferreira G., Monteiro G., Prazeres D., Cabral J., Downstream processing of plasmid DNA for gene therapy and DNA vaccine applications, Trends Biotechnol. 18 (2000) 380-388.

[25] Grayston J.T., Infections caused by Chlamydia pneumoniae strain TWAR, Clin. Infect. Dis. 15 (1992) 757-761.

[26] Gurunathan S., Klinman D.M., Seder R.A., DNA vaccines: immunology, application, and optimization, Annu. Rev. Immunol. 18 (2000) 927-974.

[27] Gurunathan S., Wu C., Freidag B., Seder R., DNA vaccines: a key for inducing long-term cellular immunity, Curr. Opin. Immunol. 12 (2000) 442-447.

[28] Hasan U.A., Abai A.M., Harper D.R., Wren B.W., Morrow W.J., Nucleic acid immunization: concepts and techniques associated with third generation vaccines, J. Immunol. Methods 229 (1999) 1-22.
[29] Héchard C., Grépinet O., Rodolakis A., Protection evaluation against Chlamydophila abortus challenge by DNA vaccination with a dnaK-encoding plasmid in pregnant and non-pregnant mice, Vet. Res. 33 (2002) 313326.

[30] Héchard C., Grépinet O., Rodolakis A., Evaluation of protection against Chlamydophila abortus challenge after DNA immunization with the major outer-membrane proteinencoding gene in pregnant and non-pregnant mice, J. Med. Microbiol. 52 (2003) 35-40.

[31] Héchard C., Grépinet O., Rodolakis A., Proteic boost enhances humoral response induced by DNA vaccination with the dnaK gene of Chlamydophila abortus but fails to protect pregnant mice against a virulence challenge, Vet. Res. 34 (2003) 119-125.

[32] Hess J., Schaible U., Raupach B., Kaufmann S.H., Exploiting the immune system: toward new vaccines against intracellular bacteria, Adv. Immunol. 75 (2000) 1-88.

[33] Igietseme J.U., Murdin A., Induction of protective immunity against Chlamydia trachomatis genital infection by a vaccine based on major outer membrane protein-lipophilic immune response-stimulating complexes, Infect. Immun. 68 (2000) 6798-6806.

[34] Igietseme J.U., Black C.M., Caldwell H.D., Chlamydia vaccines: strategies and status, BioDrugs 16 (2002) 19-35.

[35] Johnston S.A., Barry M.A., Genetic to genomic vaccination, Vaccine 15 (1997) 808 809 .

[36] Kalman S., Mitchell W., Marathe R., Lammel C., Fan J., Hyman R.W., Olinger L., Grimwood J., Davis R.W., Stephens R.S., Comparative genomes of Chlamydia pneumoniae and C. trachomatis, Nat. Genet. 21 (1999) 385-389.

[37] Kaufman R.J., Overview of vector design for mammalian gene expression, Mol. Biotechnol. 16 (2000) 151-160.

[38] Kikuta L.C., Puolakkainen M., Kuo C.C., Campbell L.A., Isolation and sequence analysis of the Chlamydia pneumoniae GroE operon, Infect. Immun. 59 (1991) 4665-4669.

[39] Krieg A.M., Immune effects and mechanisms of action of CpG motifs, Vaccine 19 (2001) 618-622.

[40] Leclercq S., Harms J.S., Oliveira S.C., Enhanced efficacy of DNA vaccines against an intracellular bacterial pathogen by genetic adjuvants, Curr. Pharm. Biotechnol. 4 (2003) 99-107.

[41] Lewis P.J., Babiuk L.A., DNA vaccines: a review, Adv. Virus Res. 54 (1999) 129-188. 
[42] Liu M.A., DNA vaccines: a review, J. Intern. Med. 253 (2003) 402-410.

[43] Longbottom D., Chlamydial vaccine development, J. Med. Microbiol. 52 (2003) 537540.

[44] Longbottom D., Coulter L.J., Animal chlamydioses and zoonotic implications, J. Comp. Pathol. 128 (2003) 217-244.

[45] Lowrie D.B., Silva C.L., Tascon R.E., DNA vaccines against tuberculosis, Immunol. Cell Biol. 75 (1997) 591-594.

[46] Lowrie D.B., Tascon R.E., Bonato V.L., Lima V.M., Faccioli L.H., Stavropoulos E., Colston M.J., Hewinson R.G., Moelling K., Silva C.L., Therapy of tuberculosis in mice by DNA vaccination, Nature 400 (1999) 269-271.

[47] Maloy K.J., Erdmann I., Basch V., Sierro S., Kramps T.A., Zinkernagel R.M., Oehen S., Kündig T.M., Intralymphatic immunization enhances DNA vaccination, Proc. Natl. Acad. Sci. USA 98 (2001) 3299-3303.

[48] Martin T., Parker S.E., Hedstrom R., Le T., Hoffman S.L., Norman J., Hobart P., Lew D., Plasmid DNA malaria vaccine: the potential for genomic integration after intramuscular injection, Hum. Gene Ther. 10 (1999) 759768.

[49] McCafferty M.C., Herring A.J., Andersen A.A., Jones G.E., Electrophoretic analysis of the major outer membrane protein of Chlamydia psittaci reveals multimers which are recognized by protective monoclonal antibodies, Infect. Immun. 63 (1995) 2387 2389.

[50] McShane H., Prime-boost immunization strategies for infectious diseases, Curr. Opin. Mol. Ther. 4 (2002) 23-27.

[51] Mor G., Plasmid DNA: a new era in vaccinology, Biochem. Pharmacol. 55 (1998) 11511153 .

[52] Mor G., Singla M., Steinberg A.D., Hoffman S.L., Okuda K., Klinman D.M., Do DNA vaccines induce autoimmune disease? Hum. Gene Ther. 8 (1997) 293-300.

[53] Mor G., Yamshchikov G., Sedegah M., Takeno M., Wang R., Houghten R.A., Hoffman S., Klinman D.M., Induction of neonatal tolerance by plasmid DNA vaccination of mice, $\mathrm{J}$. Clin. Investig. 98 (1996) 2700-2705.

[54] Murdin A.D., Dunn P., Sodoyer R., Wang J., Caterini J., Brunham R.C., Aujame L., Oomen R., Use of a mouse lung challenge model to identify antigens protective against Chlamydia pneumoniae lung infection, J. Infect. Dis. 181 Suppl. 3 (2000) S544-S551.
[55] Mygind P., Christiansen G., Persson K., Birkelund S., Analysis of the humoral immune response to Chlamydia outer membrane protein 2, Clin. Diagn. Lab. Immunol. 5 (1998) 313-318.

[56] Nichols R.L., Murray E.S., Nisson P.E., Use of enteric vaccines in protection against chlamydial infections of the genital tract and the eye of guinea pigs, J. Infect. Dis. 138 (1978) 742-746.

[57] Nichols W.W., Ledwith B.J., Manam S.V., Troilo P.J., Potential DNA vaccine integration into host cell genome, Ann. N.Y. Acad. Sci. 772 (1995) 30-39.

[58] Oshop G.L., Elankumaran S., Heckert R.A., DNA vaccination in the avian, Vet. Immunol. Immunopathol. 89 (2002) 1-12.

[59] Pal S., Theodor I., Peterson E.M., de la Maza L.M., Monoclonal immunoglobulin A antibody to the major outer membrane protein of the Chlamydia trachomatis mouse pneumonitis biovar protects mice against a chlamydial genital challenge, Vaccine 15 (1997) 575-582.

[60] Pal S., Barnhart K.M., Wei Q., Abai A.M., Peterson E.M., de la Maza L.M., Vaccination of mice with DNA plasmids coding for the Chlamydia trachomatis major outer membrane protein elicits an immune response but fails to protect against a genital challenge, Vaccine 17 (1999) 459-465.

[61] Peeling R., Maclean I.W., Brunham R.C., In vitro neutralization of Chlamydia trachomatis with monoclonal antibody to an epitope on the major outer membrane protein, Infect. Immun. 46 (1984) 484-488.

[62] Penttilä T., Vuola J.M., Puurula V., Anttila M., Sarvas M., Rautonen N., Mäkelä P.H., Puolakkainen M., Immunity to Chlamydia pneumoniae induced by vaccination with DNA vectors expressing a cytoplasmic protein (Hsp60) or outer membrane proteins (MOMP and Omp2), Vaccine 19 (2001) 1256-1265.

[63] Peterson E.M., Cheng X., Markoff B.A., Fielder T.J., de la Maza L.M., Functional and structural mapping of Chlamydia trachomatis species- specific major outer membrane protein epitopes by use of neutralizing monoclonal antibodies, Infect. Immun. 59 (1991) 4147-4153.

[64] Pisetsky D.S., The immunologic properties of DNA, J. Immunol. 156 (1996) 421-423.

[65] Read T.D., Myers G.S., Brunham R.C., Nelson W.C., Paulsen I.T., Heidelberg J., Holtzapple E., Khouri H., Federova N.B., Carty H.A., Umayam L.A., Haft D.H., Peterson J., Beanan M.J., White O., Salzberg S.L., 
Hsia R.C., McClarty G., Rank R.G., Bavoil P.M., Fraser C.M., Genome sequence of Chlamydophila caviae (Chlamydia psittaci GPIC): examining the role of niche-specific genes in the evolution of the Chlamydiaceae, Nucleic Acids Res. 31 (2003) 2134-2147.

[66] Read T.D., Brunham R.C., Shen C., Gill S.R., Heidelberg J.F., White O., Hickey E.K., Peterson J., Utterback T., Berry K., Bass S., Linher K., Weidman J., Khouri H., Craven B., Bowman C., Dodson R., Gwinn M., Nelson W., DeBoy R., Kolonay J., McClarty G., Salzberg S.L., Eisen J., Fraser C.M., Genome sequences of Chlamydia trachomatis MoPn and Chlamydia pneumoniae AR39, Nucleic Acids Res. 28 (2000) 1397-1406.

[67] Rockey D.D., Lenart J., Stephens R.S., Genome sequencing and our understanding of Chlamydiae, Infect. Immun. 68 (2000) 5473-5479.

[68] Rodolakis A., In vitro and in vivo properties of chemically induced temperature-sensitive mutants of Chlamydia psittaci var. ovis: screening in a murine model, Infect. Immun. 42 (1983) 525-530.

[69] Rodolakis A., Bernard F., Lantier F., Mouse models for evaluation of virulence of Chlamydia psittaci isolated from ruminants, Res. Vet. Sci. 46 (1989) 34-39.

[70] Saikku P., Leinonen M., Mattila K., Ekman M.-R., Nieminen M.S., Mäkelä P.H., Huttunen J.K., Valtonen V., Serological evidence of an association of a novel Chlamydia, TWAR, with chronic coronary heart disease and acute myocardial infarction, Lancet 2 (1988) 983986.

[71] Scheerlinck J.P.Y., Genetic adjuvants for DNA vaccines, Vaccine 19 (2001) 2647 2656.

[72] Shirai M., Hirakawa H., Kimoto M., Tabuchi M., Kishi F., Ouchi K., Shiba T., Ishii K., Hattori M., Kuhara S., Nakazawa T., Comparison of whole genome sequences of Chlamydia pneumoniae $\mathrm{J} 138$ from Japan and CWL029 from USA, Nucleic Acids Res. 28 (2000) 2311-2314.

[73] Srivastava I.K., Liu M.A., Gene vaccines, Ann. Intern. Med. 138 (2003) 550-559.

[74] Stagg A.J., Vaccines against Chlamydia: approaches and progress, Mol. Med. Today 4 (1998) 166-173.

[75] Stagg A.J., Elsley W.A., Pickett M.A., Ward M.E., Knight S.C., Primary human T-cell responses to the major outer membrane protein of Chlamydia trachomatis, Immunology 79 (1993) 1-9.
[76] Stephens R.S., Chlamydial genomics and vaccine antigen discovery, J. Infect. Dis. 181 Suppl. 3 (2000) S521-S523.

[77] Stephens R.S., Kalman S., Lammel C., Fan J., Marathe R., Aravind L., Mitchell W., Olinger L., Tatusov R.L., Zhao Q., Koonin E.V., Davis R.W., Genome sequence of an obligate intracellular pathogen of humans: Chlamydia trachomatis, Science 282 (1998) 754-759.

[78] Storz J., Eugster A.K., Altera K.P., Olander H.J., Behavior of different bovine chlamydial agents in newborn calves, J. Comp. Pathol. 81 (1971) 299-307.

[79] Strugnell R.A., Drew D., Mercieca J., DiNatale S., Firez N., Dunstan S.J., Simmons C.P., Vadolas J., DNA vaccines for bacterial infections, Immunol. Cell Biol. 75 (1997) 364-369.

[80] Svanholm C., Bandholtz L., Lobell A., Wigzell H., Enhancement of antibody responses by DNA immunization using expression vectors mediating efficient antigen secretion, J. Immunol. Methods 228 (1999) 121-130.

[81] Svanholm C., Bandholtz L., Castaños-Velez E., Wigzell H., Rottenberg M.E., Protective DNA immunization against Chlamydia pneumoniae, Scand. J. Immunol. 51 (2000) 345353.

[82] Tang D., DeVit M., Johnston S., Genetic immunization is a simple method for eliciting an immune response, Nature 356 (1992) 152154.

[83] Tascon R.E., Colston M.J., Ragno S., Stavropoulos E., Gregory D., Lowrie D.B., Vaccination against tuberculosis by DNA injection, Nat. Med. 2 (1996) 888-892.

[84] Ulmer J.B., Tuberculosis DNA vaccines, Scand. J. Infect. Dis. 33 (2001) 246-248.

[85] Ulmer J.B., An update on the state of the art of DNA vaccines, Curr. Opin. Drug. Discov. Devel. 4 (2001) 192-197.

[86] Ulmer J.B., Donnelly J.J., Parker S.E., Rhodes G.H., Felgner P.L., Dwarki V.J., Gromkowski S.H., Deck R.R., DeWitt C.M., Friedman A., Hawe L.A., Leander K.R., Martinez D., Perry H.C., Shiver J.W., Montgomery D.L., Liu M.A., Heterologous protection against influenza by injection of DNA encoding a viral protein, Science 259 (1993) 1745-1749.

[87] van Drunen Littel-van den Hurk S., Loehr B.I., Babiuk L.A., Immunization of livestock with DNA vaccines: current studies and future prospects, Vaccine 19 (2001) 24742479.

[88] Vanrompay D., Ducatelle R., Haesebrouck F., Chlamydia psittaci infections: a review 
with emphasis on avian chlamydiosis, Vet. Microbiol. 45 (1995) 93-119.

[89] Vanrompay D., Cox E., Volckaert G., Goddeeris B., Turkeys are protected from infection with Chlamydia psittaci by plasmid DNA vaccination against the major outer membrane protein, Clin. Exp. Immunol. 118 (1999) 49-55.

[90] Vanrompay D., Cox E., Vandenbussche F., Volckaert G., Goddeeris B., Protection of turkeys against Chlamydia psittaci challenge by gene gun-based DNA immunizations, Vaccine 17 (1999) 2628-2635.

[91] Vanrompay D., Cox E., Kaiser P., Lawson S., Van Loock M., Volckaert G., Goddeeris B., Protection of turkeys against Chlamydophila psittaci challenge by parenteral and mucosal inoculations and the effect of turkey interferon- $\gamma$ on genetic immunization, Immunology 103 (2001) 106-112.

[92] Widera G., Austin M., Rabussay D., Goldbeck C., Barnett S.W., Chen M., Leung L., Otten G.R., Thudium K., Selby M.J., Ulmer J.B., Increased DNA vaccine delivery and immu- nogenicity by electroporation in vivo, $\mathrm{J}$. Immunol. 164 (2000) 4635-4640.

[93] Wolf K., Fischer E., Mead D., Zhong G., Peeling R., Whitmire B., Caldwell H.D., Chlamydia pneumoniae major outer membrane protein is a surface-exposed antigen that elicits antibodies primarily directed against conformation-dependent determinants, Infect. Immun. 69 (2001) 3082-3091.

[94] Wolff J.A., Malone R.W., Williams P., Chong W., Acsadi G., Jani A., Felgner P.L., Direct gene transfer into mouse muscle in vivo, Science 247 (1990) 1465-1468.

[95] Zhang D.-J., Yang X., Shen C., Brunham R.C., Characterization of immune responses following intramuscular DNA immunization with the MOMP gene of Chlamydia trachomatis mouse pneumonitis strain, Immunology 96 (1999) 314-321.

[96] Zhang D.-J., Yang X., Berry J., Shen C., McClarty G., Brunham R.C., DNA vaccination with the major outer-membrane protein gene induces acquired immunity to Chlamydia trachomatis (mouse pneumonitis) infection, J. Infect. Dis. 176 (1997) 1035-1040. 